\title{
International climate change negotiation: the role of Brazil
}

\author{
Negociação internacional da mudança do clima: o papel \\ do Brasil
}

\author{
Marcela Cardoso Guilles da Conceição ${ }^{a}$ \\ Renato Aragão Ribeiro Rodrigues ${ }^{b}$ \\ Fernanda Reis Cordeiro ${ }^{c}$ \\ Fernando Vieira Cesário ${ }^{d}$ \\ Gracie Verde Selva ${ }^{\mathrm{e}}$ \\ Carolinna Maria ${ }^{f}$ \\ Eduardo da Silva Matos ${ }^{g}$ \\ Renato Campello Cordeiro ${ }^{h}$ \\ Edison Dausacker Bidone
}

${ }^{a}$ Doutora em Geociências, Departamento de Geoquímica, Universidade Federal Fluminense, UFF, Niterói, RJ, Brasil E-mail:marcelaguilles.clima@gmail.com

\begin{abstract}
${ }^{b}$ Pesquisador da Empresa Brasileira de Pesquisa e Agropecuária, Embrapa Solos, Rio de Janeiro, RJ, Brasil E-mail: renato.rodrigues@embrapa.br

'Mestranda em Agronomia, Universidade Federal Rural do Rio de Janeiro, UFRRJ, Rio de Janeiro, RJ, Brasil E-mail: fereis.cordeiro@gmail.com

${ }^{d}$ Doutor em Geografia, Universidade Federal Fluminense, UFF, Niterói, RJ, Brasil E-mail: fernandovieiracesario@gmail.com

${ }^{e}$ Consultora, Instituto Brasileiro de Desenvolvimento e Sustentabilidade, IABS, Brasília, DF, Brasil

E-mail: gracieselva@gmail.com
\end{abstract}

${ }^{f}$ Doutoranda em Relações Internacionais, Pontificia Universidade Católica de Minas Gerais, Belo Horizonte, MG, Brasil E-mail: carolinnamaria1@gmail.com

'Pesquisador da Empresa Brasileira de Pesquisa e Agropecuária, Secretaria de Inteligência e Relações Estratégicas, Brasília, DF, Brasil

E-mail: eduardo.matos@embrapa.br

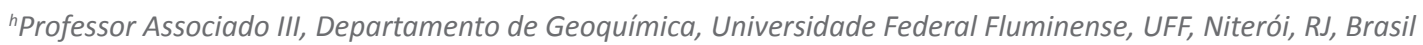
E-mail: rccordeiro@geoq.uff.br

iProfessor Titular do Departamento de Geoquímica, Universidade Federal Fluminense, UFF, Niterói, RJ, Brasil E-mail: ebidone@yahoo.com.br 


\section{ABSTRACT}

The increase of greenhouse gases in the atmosphere raises the average temperature of the planet, triggering problems that threaten the survival of humans. Protecting the global climate from the effects of climate change is an essential condition for sustaining life. For this reason, governments, scientists, and society are joining forces to propose better solutions that could well-rounded environmentally, social and economic development relationships. International climate change negotiations involve many countries in establishing strategies to mitigate the problem. Therefore, understanding international negotiation processes and how ratified agreements impact a country is of fundamental importance. The purpose of this paper is to systematize information about how climate negotiations have progressed, detailing key moments and results, analyzing the role that Brazil played in the course of these negotiations and the country's future perspectives.

Keywords: Intergovernmental Panel on Climate Change. United Nations Framework Convention on Climate Change. Conference of the Parties. Sustainable Development. Low Carbon Agriculture.

\section{RESUMO}

O aumento dos gases de efeito estufa na atmosfera eleva a temperatura média do planeta, desencadeando problemas que ameaçam a sobrevivência do ser humano. A proteção do clima global frente aos efeitos das mudanças climáticas é uma condição essencial para a sustentação da vida. Por essa razão, governos, cientistas e a sociedade estão unindo forças para propor melhores soluções que possam agregar relações de desenvolvimento ambiental, social e econômico. As negociações internacionais sobre a mudança do clima envolvem muitos países no estabelecimento de estratégias para a mitigação do problema. Portanto, entender os processos internacionais de negociação e de que maneira os acordos ratificados impactam um país são de importância fundamental. $O$ objetivo deste artigo é sistematizar informações sobre como as negociações têm procedido, detalhando momentos chave e os resultados, analisando o papel que o Brasil desempenhou no decorrer dessas negociações e as perspectivas futuras do País.

Palavras-Chave: Painel Intergovernamental em Mudança do Clima. Convenção-Quadro das Nações Unidas sobre Mudança do Clima. Conferência das Partes. Desenvolvimento Sustentável. Agricultura de Baixo Carbono.

\section{INTRODUCTION}

In 1988, the United Nations Environment Program (UNEP) and the World Meteorological Organization (WMO) established the Intergovernmental Panel on Climate Change (IPCC), an intergovernmental body of the United Nations with the purpose of scientifically evaluating the possible socioeconomic and environmental impacts of climate change and formulating realistic strategies to deal with the problem (MIGUEZ, 2002). Their reports are essential to recognizing the effect of greenhouse gases (GHG) on the climate system. The first IPCC assessment report, AR1, was published in 1990 and featured work on two items: (a) evaluation of how developing countries could increase their participation and cooperation with IPCC work and (b) elements for implementing future work on international cooperation within the theme (IPCC, 1990).

The Second World Climate Conference (WCC), held in Geneva in 1990, was the starting point for discussions on the establishment of the United Nations Framework Convention on Climate Change 
(UNFCC) (hereinafter referred to as the Convention), a treaty between almost every country in the world setting the principles, norms, roles and cooperation between the parties for decision-making on climate change. The Intergovernmental Negotiating Committee for the Convention was established in the same year at the United Nations General Assembly, and the participating countries signed the document at the United Nations Conference on Environment and Development (Rio 92) in 1992 (MENDES, 2014). Brazil was the first country to sign the agreement and had a significant presence in international environmental articulations and debates.

The Convention that was implemented in 1994 convenes the participating countries once a year at the Annual Conference of the Parties (COP), which features discussions, debates, results, agreements, and decision-making on the challenges of economic development, environmental maintenance and social problems in the face of climate change (CENCl, 2020).

The Convention follows the principle of multilateralism, which is contained in the UN Charter, and considers that each signatory country is a party to the agreement (hence the term "Conference of the Parties") and that any decision taken must be consensual, not determined by a simple majority of votes. Moreover, decisions are part of a global agreement of interest to all Parties. In the language of negotiation: "nothing is decided until everything is decided" (UNFCCC, 1992).

For its time, considering the lack of full knowledge about the processes and impacts of climate change, the text of the Convention brought significant advances to the discussion of the environment. The Convention recognized, amongst other points, that (UNFCCC, 1992):

- Earth's climate change and its adverse effects are a common concern of humanity;

- The largest share of global, historical and current emissions of greenhouse gases originates in developed countries;

- Per capita emissions from developing countries are still relatively low, and the share of global emissions from developing countries will grow so that they can meet their social and development needs.

Moreover, the ultimate objective was to "achieve stabilization of GHG concentrations in the atmosphere at a level that would prevent dangerous anthropogenic interference with the climate system" (UNFCCC, 1992, p4). The text further warned that such a level should be achieved within a sufficient period to enable ecosystems to adapt naturally to climate change, ensure that food production is not threatened, and enable economic development to proceed sustainably.

The Convention imposed a set of targets for GHG emission reductions for some countries, mainly the developed ones, listed in the Convention Annex I. The Convention did not impose initial emission reduction targets for developing and least developed countries (UNFCCC, 1992), because the developed countries accounted for most of the emissions, most of the concentration of gases in the atmosphere, and the rise in the average temperature of the planet. Further, Annex I listed countries were required to promote policies and measures for the reduction of emissions to reach the emission level of the year 1990 , a commitment that has not been achieved.

The Convention still contains two fundamental principles for the consolidation of international negotiation and sustainable development, especially in developing countries (UNFCCC, 1992):

- Precautionary Principle: Lack of full scientific certainty should not be used as a reason for countries to postpone measures to predict, prevent, or minimize the causes of climate change and mitigate its adverse effects.

- Principle of Common but Differentiated Responsibilities: Parties shall protect the climate system for the benefit of present and future generations based on equity and following their common but differentiated responsibilities and respective capabilities. In this regard, 
developed country Parties should take the lead in addressing climate change and the adverse impacts of climate change.

The Convention, through the Principle of Common but Differentiated Responsibilities, proposed a series of commitments common to all signatory Parties, such as:

- Preparation of a National Communication, containing the inventory of anthropogenic GHG emissions by gas and economic sector;

- Promotion of mitigation and adaptation programs;

- Development of technologies for emission reduction and prevention;

- Protection of carbon sinks, such as forests and oceans;

- Consideration of climate change in social, economic and environmental policies;

- Promotion of scientific research on climate change;

- Promotion of education, training and awareness actions.

A plethora of decisions and documents have been produced throughout the more than 20 years of negotiation. This paper will explore seven crucial moments that occurred during this extensive process of negotiations and future perspectives of Brazil's role in international negotiations. In chronological order (Figure 1) we will present and discuss the main issues of the first COP and the Brazilian Proposal;

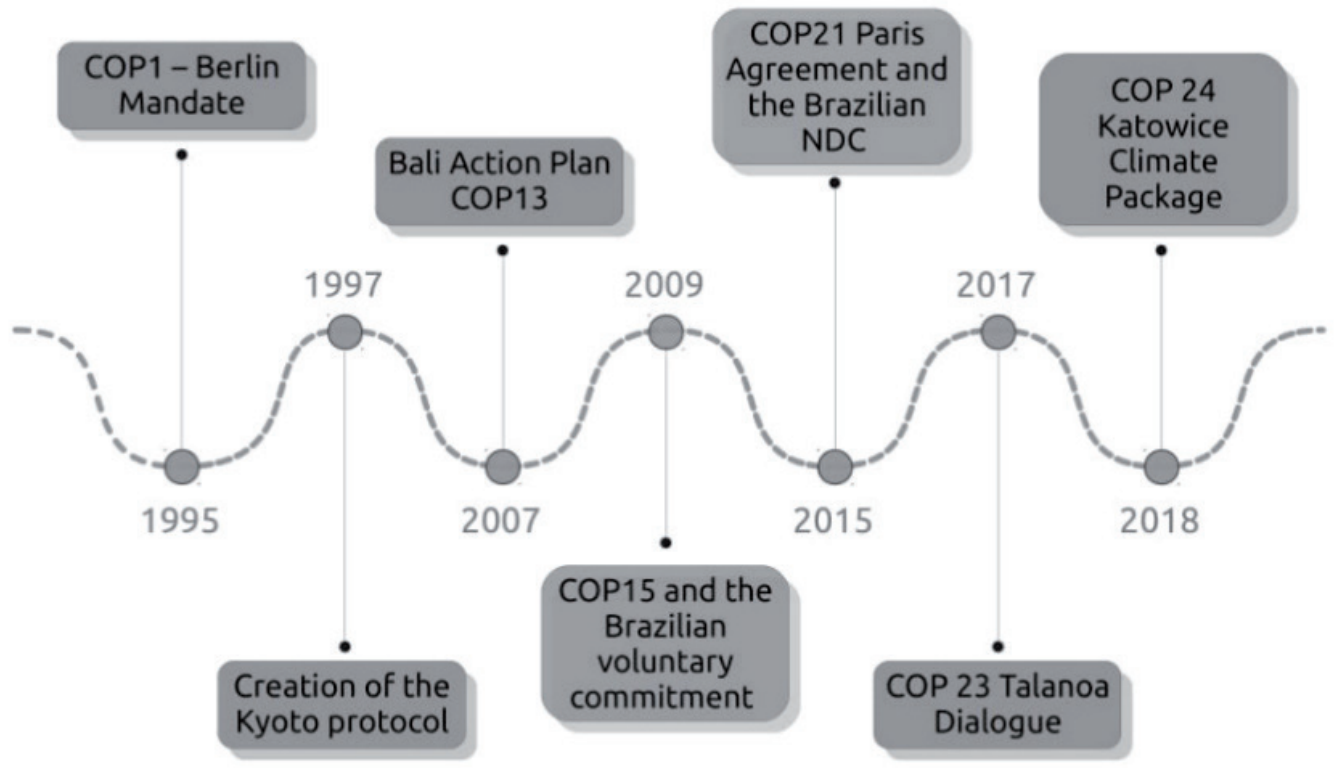

the creation of the Kyoto Protocol; the Bali Action Plan; COP15 and Brazil's voluntary commitment; COP21, the Paris Agreement and Brazil's Nationally Determined Contribution; the Talanoa Dialogue and finally COP24 and the Katowice Climate Package.

Figure 1 | Chronological order of the international negotiations events for climate change. Source: elaborated by the authors

\section{MATERIAL AND METHODS}

To conduct this research the method of literature review was used. First, fifteen key terms were defined for our topic: Climate change; International negotiations; Greenhouse gases; Intergovernmental Panel on Climate Change; United Nations Framework Convention on Climate Change; Conference of the 
Parties; Environmental maintenance; Challenges of economic development; Kyoto Protocol; Paris Agreement; Brazil's Nationally Determined Contribution; Talanoa Dialogue; Katowice Climate Package; Bali Action Plan and Low Carbon Agriculture Plan of National policy on climate change.

Second, a systematic search was conducted using library catalogs, abstracts and reviews, citation indexes, bibliographies, websites and national and international journals. We restrict the search to Portuguese and English, focusing on literature between 1990 and 2018. The web-based search was proceeded using only seven websites: Google Scholar, Science Direct, Springerlink, Scielo, ERIC, Science. gov, and ScienceResearch.

For each website, we include items embracing thesis, scientific papers, books, book chapters, reviews, reports, and government documents. All documents were identified in three categories: i) broader documents, that is, documents that match one key term, but the scope is not related to climate theme or is not related to Brazil; ii) related documents, that is, documents that match key term and the theme embrace climate and Brazil; iii) narrower documents, that is, documents that exactly about International climate change negotiations involving Brazil. Finally, a list of 187 key references was obtained and 94 evaluated. As exclusion criteria, we exclude documents that are focusing mainly on the effects of climate on biophysical systems; documents that not included negotiations strategies, or are not clear; documents that not mention sustainable Brazil programs.

\section{INTERNATIONAL NEGOTIATION ON CLIMATE CHANGE}

\subsection{COP1 AND THE BRAZILIAN PROPOSAL}

The first COP was held in Berlin in 1995, after the actual implementation of the Convention in 1994. At that first meeting, it was already possible to identify that there existed an increase in GHG emissions and that the initial goal of emission reductions proposed for developed countries would be insufficient. The proposed solution was "jointly implemented activities", presented in the document called the "Berlin Mandate" (Ad Hoc Group on the Berlin Mandate - AGBM).

At this COP, Brazil played an important role in presenting elements for a protocol in response to the Berlin Mandate, known as the "Brazilian Proposal". This Proposal was a very innovative approach, and the document presented two elements to support discussion regarding the future negotiation process (UNFCCC, 1997): (a) the Proposal of objective criteria to establish the individual responsibility of Annex I countries in relation to the causes of the greenhouse effect; and (b) the idea of a Clean Development Fund.

This proposal assumed that the responsibility of each country should not be taken solely concerning its GHG emissions or its contribution to increasing the concentration of GHG in the atmosphere. Thus, as the higher concentrations of GHG in the atmosphere increase the planet's temperature, the responsibility of each country must also be related to its contribution to the increase of global temperature. This difference in parameters implies that Annex I countries have made an even more significant contribution to the problem, as shown in Figure 2. 


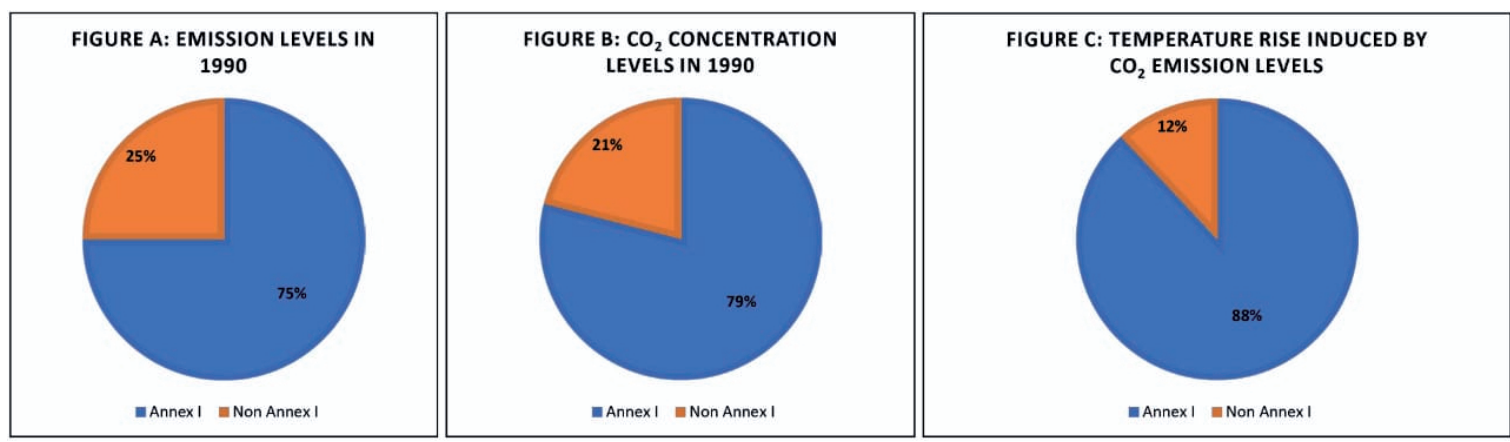

Figure 2: Relative contribution allocated to each Party according to the First Report of the IPCC (1990). Source: adapted from FRONDIZI (2009).

\subsection{CREATION OF THE KYOTO PROTOCOL}

The Brazilian proposal, in the first COP, was not entirely accepted by the developed countries (BRAZIL, 2010), but it provided influential subsidies for international negotiations and was a precursor to the COP3 decision (in 1997) with the signing of the Kyoto Protocol, which conferring real regard to the human influence on climate (OPPENHEIMER et al., 2007). At the moment, Brazil start to emerge as a climate mitigation-wise country.

The Kyoto Protocol was the first legally binding agreement to reduce GHG emissions and created three important mechanisms for industrialized countries to meet their reduction targets; which are Emissions trading, Joint implementation and the Clean Development Mechanism (CDM) (MAAMOUN, 2019; UNFCCC, 1998).

However, for the Kyoto Protocol to enter into force, two requirements were necessary: (a) at least 55 Convention countries would have to ratify the Protocol, and (b) the inclusion of Annex I countries representing at least 55\% of total CO2 emissions in 1990 (UNFCCC, 1998).

These requirements somehow embraced a twofold way and gave the US and Russia veto power, polarizing these countries again after the cold war, a kind of climate war. This is because if one of them did not ratify the agreement, the value of $55 \%$ of emissions would not be reached. The US did not accede to the agreement but made its participation conditional to any Convention protocol if commitments to limit and reduce GHG emissions were also made by developing countries in the same period. This a priori political US position seems to be intended to safeguard a privileged position in the global scenario, however, it may have been the key to the effectiveness of the protocol (MAAMOUN, 2019; MOSS et al., 2008).

An intense negotiation period followed until the US announced, in March 2001, that they would not ratify the Protocol. With that, the only way forward was to ensure Russia's presence in the agreement, which was finally granted on November 4, 2004.

Since the ratification of the Kyoto Protocol in 2004, there has been a significant change in the negotiation process resulting in "two tracks": the Convention (Ad Hoc Working Group on Long-term Cooperative Action - AWG-LCA - ad hoc group for long-term dialogues for the implementation of the Convention) and the Kyoto Protocol (Ad Hoc Working Group on Further Committees for Annex I Parties under the Kyoto Protocol - AWG-KP - ad hoc group for establishing the Kyoto Protocol). Thus, the COP came to host a new modality of meeting: the COP/MOP, where the Conference of the Parties serves as the basis for the meeting of the Kyoto Protocol.

Maamoun (2019) assessed emissions data from countries committed to the Kyoto protocol and found that the protocol was a successful first step. The author noted that the protocol prevented a worse emission level from occurring even though leading countries in GHG emissions, such as the US, did not participate in the agreement. 


\subsection{BALI ACTION PLAN}

During the COP13 (2007) in Bali (Indonesia), the Bali Action Plan (BAP) was created to guide negotiations until COP15, when a new legally binding agreement was expected. The BAP was composed of negotiating areas, the main ones being: expanded international and national action on mitigation, expanded action on adaptation and expanded action on technology transfer and development (UNFCCC, 2008).

The expanded mitigation action negotiation area was subdivided into six areas: (i) mitigation in Annex I countries; (ii) mitigation in non-Annex I countries; (iii) reduce emissions from deforestation and forest degradation and maintain soil carbon stocks through forest management; (iv) market; (v) economic measures and (vi) social measures.

Reducing emissions from deforestation and forest degradation has the acronym REDD while reducing emissions from deforestation and forest degradation, maintaining soil carbon stocks through forest management has the acronym REDD+. This area deserves attention, as it refers to a mechanism that allows compensation to those who maintain forests without deforestation, avoiding greenhouse gas emissions, plus conservation activities, sustainable forest management, and increased stocks in developing countries (ARTS; INGRAM; BROCKHAUS, 2019).

The BAP proposed to intensify mitigation measures under three premises (UNFCCC, 2008):

- Measurable, reported and verified (MRV) commitments or mitigation measures for each country, including quantified emission limitation and reduction targets, from all Annex I Parties, ensuring comparability between them and taking into account differences in national circumstances;

- Country-appropriate mitigation measures for non-Annex I Parties, in the context of sustainable development, with appropriate technological, financial and capacity support, to enable MRV requirements to be met;

- Approaches to cross-sectoral cooperation and sector-specific measures to improve implementation of Article 4, paragraph 1 (c) of the Convention, which is primarily measures to promote and cooperate with development including technology transfer and commitments that control, reduce or prevent anthropogenic GHG emissions.

Developing countries do not have emission reduction targets. However, the BAP demanded that the implementation of the Convention were extended with nationally appropriate mitigation actions, leading to a substantial deviation of emissions from non-Annex I countries from the trend path. These actions were to be supported by Annex I countries in terms of financing, technology transfer, and capacity building.

Thus, Brazil has the following examples of mitigation actions (BRAZIL, 2010):

- Deforestation: further reduction of deforestation focusing on the Amazon and Cerrado;

- Energy: energy efficiency, increased use of biofuels, an increased supply of energy by hydropower, alternative sources of energy;

- Agriculture: recovery of degraded pastures, crop-livestock integration, no-tillage system, biological nitrogen fixation;

- Industry: increased reforestation area for coal production for the steel industry.

Brazil's participation increased the significant effort to reduce emissions already made in the country in order to achieve a substantial slowdown in its emissions growth. According to the Brazilian view of the time, mitigation actions should not be a means of offsetting emissions from the Annex I countries, because it was an agreement under the Convention where there are no mandatory targets for developing countries, but a framework that guides developing countries in terms of mitigating climate change. 
Concerning broadened action on adaptation, the BAP takes into account international cooperation for the urgent implementation of adaptation measures to the adverse effects of climate change in developing and least developed countries. Also, for these countries, it provides for risk management and mitigation strategies, disaster reduction strategies, economic diversification to increase resilience and synergies between activities and processes as a way of supporting adaptation in a coherent and integrated manner (UNFCCC, 2008).

With respect to expanded action in technology transfer and development, the BAP aims to remove obstacles and provide financial resources, accelerate the diffusion and expansion of technology deployment as well as promoting cooperation between research and development (R\&D) for current, new and innovative technologies (UNFCCC, 2008).

\subsection{COP15 AND THE BRAZILIAN VOLUNTARY COMMITMENT}

The Copenhagen Conference in 2009 (COP15) generated high expectations from the Parties, the world press and society. A new, broadly and legally binding agreement was expected to bring a "solution" to the problem of climate change. Under pressure from all sides, the COP presidency considered necessary to present a proposal. That was the moment the Copenhagen Accord was created.

The Copenhagen Accord presented legal and procedural problems that hindered its operation. It was prepared by 29 countries and had the direct participation of several Heads of State. Several parties formally rejected it based on various procedural irregularities denounced during the Conference. The main problem was the lack of consensus, which would be enough to make the Accord non-operational. The COP observed the rejection of the Accord expressed by some parties, becoming a document without legal value. Consequently, it is not part of the official architecture of the Convention and has been repeatedly challenged by the Parties that have rejected it (DIMITROV, 2010).

However, although the general outcome of COP15 was not as expected, for Brazil it was significant, especially for the agricultural sector. During COP15, Brazil made a voluntary commitment to reduce emissions, playing a crucial role in the negotiations and motivating other developing countries to send voluntary commitments as well. The Brazilian commitment foresees a reduction of $36.1 \%$ to $38.9 \%$ of projected emissions by 2020, thus avoiding the emission of about 1 billion tons of $\mathrm{CO} 2$ equivalent (tCO2e), which represents the most significant reduction effort on the planet (BRAZIL, 2010).

In late January 2010, Brazil submitted to the Convention Secretariat two reports ratifying mitigation actions appropriate to the national context that had been proposed in Copenhagen. It also expressed, with due caution, its accession to the Copenhagen Accord. The proposals presented in Copenhagen were internalized by Law 12.187/09, which instituted the National Policy on Climate Change.

In 2010, Sectoral Plans were created to achieve this voluntary commitment, among them the ABC (Low Carbon Agriculture) Plan. According to Rodrigues and Galvão (2018), the National Policy on Climate Change established institutions that would be responsible for the governance of an essentially environmental policy with direct connections to the performance of the Brazilian economy, as demanded by the Brazilian climate change policy.

\subsection{COP21, THE PARIS AGREEMENT AND THE BRAZILIAN NDC}

Following the unmet expectations at COP15 and the hard work of regaining confidence in the multilateral process of the United Nations Framework Convention on Climate Change and its signatory countries, COP21, which took place in Paris, had the mission to finally reach a legally binding global agreement that could meet the objective requirements of the Convention (MILKOREIT, 2019). 
Lower expectations from the press and civil society facilitated the process, and the outcome of the Conference was the Paris Agreement, which was opened for ratification in April 2016. The Parties to the Agreement reflected the original content of the Convention, seeking to achieve the goals guided by the principles, justice and common but differentiated responsibilities, and their respective capacities, according to their different national circumstances.

The Agreement was marked by recognizing the need to respond effectively to the threats of climate change, based on substantial scientific knowledge, and the need to identify which countries could be most affected by climate change and also the measures taken by them. Priority was placed on ensuring food security and eradicating hunger, defending and protecting food production systems from the negative impacts of climate change, as well as recognizing the importance of conserving and strengthening anticipated greenhouse gas sinks and reservoirs (SHARMA; PAYAL, 2019). It was recognized that the adoption of sustainable lifestyles and sustainable consumption and production patterns will play an essential role in combating climate change, with developed countries taking the lead (UNFCCC, 2015).

By strengthening the implementation of the Convention, including its objective, this Agreement aims to strengthen the global response to the threat of climate change in the context of sustainable development and poverty eradication efforts, including (UNFCCC, 2015):

I. To maintain the overall average temperature increase below $2^{\circ} \mathrm{C}$ above pre-industrial levels and to make efforts to limit this temperature increase to $1.5^{\circ} \mathrm{C}$ in relation to pre-industrial levels, recognizing that this would reduce the risks and impacts of climate change;

II. To increase the capacity to adapt to the negative impacts of climate change and promote resilience to climate change and low GHG emissions in a way that does not threaten food production; and

III. To make financial flows compatible with a path towards low GHG emissions and resilient to climate change.

The adoption by consensus that the increase in global average temperature should not exceed $2^{\circ} \mathrm{C}$ was an essential complement to the central objective of the Convention. The limitations of using annual GHG emissions inventories and applying different metrics for gas equivalence were also identified. It has been shown that, for mitigation target-based policy monitoring, the Global Temperature Change Potential (GTP) metric is more appropriate than the Global Warming Potential (GWP) metric currently most commonly used in inventory and mitigation policy analysis (MENDES, 2014).

In the IPCC's first assessment report, the GWP is proposed as a method for comparing the potential climate impact of different non-CO2 GHGs as a $\mathrm{CO} 2$ equivalent unit. However, the use of GWP does not explain the magnitude of climate change, and scientists have proposed GTP as an alternative measure to GWP to assess its potential impact on increasing planetary surface temperature (KUMARI et al., 2019).

Article 3 of the Agreement brings a new dimension to the action strategies of countries regarding the mitigation of GHG emissions, with measures more appropriate to the reality of each Party. However, it was recognized that countries of Annex I have greater participation in the status quo of the GHG emissions problem, and the difficulties that non-Annex I countries will encounter in achieving these reductions (UNFCCC, 2015, p. 22).

In this way, we return to the main objective of the Convention, which seeks to limit the rise in the average temperature of the planet in the short term through the immediate reduction of emissions from developed countries, and in the short to medium-long term for developing countries. Commitments to 
reduce emissions by country or by block of countries (such as the European Union) must be notified to the Convention through "Nationally Determined Contributions" (NDC).

Brazil was the first country to ratify the Paris Agreement, presenting its NDC to reduce emissions. The delivery of this document before COP21 was intended to demonstrate Brazil's goodwill with international negotiations and the signing of a legally binding agreement, in line with the Convention's guidelines and principles. The initial document used the term "intended" (iNDC) because, at the time, it still depended on the ratification, acceptance or approval of the Paris Agreement, and could thus be adjusted.

In its iNDC, Brazil proposed actions to mitigate GHG emissions and actions for adaptation to the effects of climate change, as well as outlining ways to implement these actions in the country and other developing countries through South-South cooperation based on solidarity and shared priorities for sustainable development. In expanding cooperation initiatives to other developing countries, the area of resilient and low-carbon agriculture plays a prominent role (BRAZIL, 2015).

Regarding mitigation, Brazil committed to reducing GHG emissions by 37\% below 2005 levels by 2025, in addition to a subsequent indicative contribution to reduce GHG emissions by $43 \%$ below 2005 levels by 2030. The reference year 2005 uses the emissions as calculated in the inventory in Brazil's second communication to the UNFCCC, which was the official document lodged with the United Nations when the iNDC was announced on September 2015 (BRAZIL, 2015).

This reduction of emissions may occur throughout the national territory for the whole economy, including $\mathrm{CO} 2, \mathrm{CH} 4, \mathrm{~N} 2 \mathrm{O}$, perfluorocarbons, hydrofluorocarbons, and SF6. The metric adopted was the Global Warming Potential in 100 years (GWP-100) using IPCC AR5 values.

Among the mitigation actions presented by Brazil, the following stand out (BRAZIL, 2015):

I. Increase the share of sustainable bioenergy in the Brazilian energy matrix to approximately $18 \%$ by 2030 , expanding biofuel consumption, increasing ethanol supply, including increases in the share of advanced biofuels (second generation), and enlarging the share of biodiesel in the blend of diesel;

II. In the forest sector and in terms of land-use change, strengthen compliance with the Forest Code at the federal, state and municipal levels; strengthen policies and measures aimed at achieving zero illegal deforestation in the Brazilian Amazon by 2030 and offset GHG emissions from legal vegetation suppression by 2030; restore and reforest 12 million hectares of forest by 2030 for multiple uses; expand sustainable native forest management systems through georeferencing and traceability systems applicable to native forest management to discourage illegal and unsustainable practices;

III. In the energy sector, achieve an estimated $45 \%$ share of renewable energy in the energy matrix by 2030 , including: expanding the use of renewable sources to between $28 \%$ to $33 \%$ by 2030; expand domestic use of non-fossil energy sources by increasing the share of renewable energy (in addition to hydropower) in electricity supply to at least $23 \%$ by 2030 , including wind, biomass and solar energy increases; achieve $10 \%$ efficiency gains in the electricity sector by 2030;

IV. In the agricultural sector, strengthen the strategy for sustainable intensification in agriculture, including restoring an additional 15 million hectares of degraded pasture by 2030 and increasing by 5 million hectares the area with integrated crop-livestock-forest systems (ICLF) by 2030 . 
This new commitment, in addition to the one proposed by Brazil at COP15, largely reinforces the consolidation of low carbon agriculture and, in particular, the recovery of degraded pastures and ICLF, as a real way to achieve sustainable intensification of agricultural production. These technologies contribute to the mitigation of greenhouse gas emissions, increase productivity and income, increase social benefits to producers and consolidate sustainable development.

\subsection{TALANOA DIALOGUE}

The Paris Agreement will only come into force in 2020. Thus, during the COP 23 held in Germany in 2017, the Talanoa Dialogue was created with the aims to encourage UNFCCC signatory countries to strengthen their commitments to curb global warming during the period before 2020 (LESNIEWSKA; SIEGELE, 2018). The Talanoa Dialogue consists of an international platform where all countries can share their actions to combat climate change and thus exchange experiences.

Talanoa is a word used to reflect an inclusive, participatory, and transparent dialogue process in Fiji and other Pacific islands. Talanoa's goal is to share stories, build empathy, and make wise decisions for the collective good. The Talanoa process involves the sharing of ideas, skills, and experiences through narrative (UNFCCC, 2018).

In Brazil, this inclusive dialogue process began on August 2, 2018, at an event called Talanoa Dialogue - Brazil, coordinated by the Ministry of the Environment and the Ministry of Foreign Relations, with support from the World Bank. This event took place in Rio de Janeiro and was attended by more than 30 representatives from different sectors (government, the private sector, academia, civil society, and rural settlement communities). Throughout the year 2018, several Talanoas occurred in Brazil, organized by different sectors of society.

\subsection{KATOWICE CLIMATE PACKAGE}

With the creation of the Paris Agreement at COP 21, the next step was to create a way to implement the Agreement. Thus, during the Conference of the Parties (COP24) in Katowice, Poland (2018), the parties adopted a package of guidelines for implementing the Paris Agreement, called the Katowice Climate Package. The main objective of the Package is to operationalize the climate change regime contained in the Paris Agreement.

The Katowice package includes (UNFCCC, 2019):

- The transparency mechanism, which details how to measure national efforts to operationalize the transparency framework jointly and the definition of how countries will provide information about their NDCs with their respective mitigation and adaptation actions;

- Guidelines related to the process of establishing new funding targets from 2025, based on the current goal of mobilizing $\$ 100$ billion per year from 2020 to support developing countries, as well as guidelines to assess progress in the development and transfer of technology;

- Rules on how to update each country's goals in five-year cycles, among other items.

Furthermore, the Climate Package emphasizes the urgent need to increase the mobilization of climate finance. On the other hand, issues such as the use of cooperative approaches and sustainable development mechanism, as set out in Article 6 of the Paris Agreement, are still pending. The use of such a mechanism would allow countries to meet some of their national mitigation targets through the use of so-called "market mechanisms". The idea of these market mechanisms is to provide flexible instruments to reduce the costs of mitigation actions, for example, through the use of carbon markets. 
Thus, the outcome document of COP24 underscores the importance of strengthening countries responsibility in replenishing the impact of programs of the Global Environment Facility. It also requests that the Global Environment Facility ensures that its policies and procedures relating to the consideration and review of funding proposals are duly and efficiently followed up. Further, the document looks forward to the planned delivery of reductions in GHG emissions in the seventh replacement period, which is double than foreseen for the sixth replacement period.

For some critics, from a climate point of view, Katowice failed (OBSERVATÓRIO DO CLIMA, 2019). For them, the Package failed to adequately capture the sense of urgency communicated by science about action against climate chaos. Also, it left in the hands of the individual countries any decision on how to use this information. For Patricia Espinosa, the Executive Secretary of the UNFCCC, Katowice was a success: "The result of Katowice is a breakthrough that all governments can be proud of! It strengthens the Paris Accord and opens the door to implementing climate action around the world!" (UNITED NATIONS CLIMATE CHANGE, 2019).

\section{FUTURE PERSPECTIVES OF BRAZIL IN CLIMATE NEGOTIATIONS}

The world went through the industrial race and countries like England, France and Germany came out ahead. In a second moment, we had a technological race, for example, the space race and advances in computing. Since the 1990s, there has been an increase in environmental concern, which is linked to sustainable production. This fact paved the way for environmental protagonism in the world. However, there is no environmental power yet. There is still no country that is promoting sustainable development by aligning environmental preservation, that's because big challenges must be faced and cooperation between the countries is essential.

Some authors argue for the possibility of economic development and environmental preservation through strategic decision-making among government agencies, industry players, and non-governmental organizations following the Sustainable Development Goals developed by the ONU (OPOKU, 2019). However, other authors raise the issue that sustainable development prioritizes economic development and will inevitably cause damage to environmental preservation.

These authors argue that the path to environmental preservation would be an economic downturn through an awareness of society concerning the high consumption, aiming at the search for social equity and human well-being (SANDBERG; KLOCKARS; WILÉN, 2019). However, from this discussion, questions emerge that still have no answer. Will current or future technology be able to increase productivity and preserve the environment to optimal limits? Nevertheless, would not a greater awareness of society and a quest for social equality be an essential pillar of sustainable development? Thus, a possible solution would be in the middle path, which is a balance between the social, economic, and environmental aspects.

A descriptive analysis conducted by Sforna (2019) shows that most developing countries demonstrates a willingness to actively contribute to climate change mitigation in cooperation with developed countries. However, external support requirements in the form of technology transfer, training, and financial support are paramount for these countries. At the same time, the author shows that the demand for climate finance from developing countries is higher than the current supply from developed countries and that trying to fill this gap is one of the critical challenges to controlling GHG emissions and thus reducing the catastrophic effects of climate change.

Brazil, however, is a country that has a higher potential to assume the role of great green power on the planet, especially when it comes to agriculture and biodiversity. Regarding agriculture development, environmental, and biodiversity protection, some countries, especially Brazil, have the opportunity to be future agri-environmental world potency. This opportunity is significant, as countries like Brazil 
will no longer achieve the technological status of developed countries. Thus, there is an opportunity for Brazil's agri-environment role in the world, but this will make future negotiations much more complicated and force the government to act intelligently.

In the last 45 years, Brazil has consolidated itself as a significant agricultural power. Grain production grew more than fivefold, while the planted area increased by only $60 \%$. However, the most significant boost has occurred since 1990, partly due to the growth in exports, which have become the driving force of recent growth in Brazilian agribusiness. The country is currently the leading exporter of orange juice, coffee, pulp and paper, chicken meat, soy complex, and the second largest exporter of sugar and corn (USDA, 2017).

The total area of land occupied and in use in Brazil is approximately $30 \%$, while Permanent Preservation Areas (indigenous lands and protected areas) and areas of native vegetation on private properties, separated according to environmental legislation-such as Legal Reserve - represent almost $50 \%$ of the Brazilian territory. If added to the native vegetation in unregistered lands, this percentage reaches $66 \%$. Crops and planted forests occupy only $9 \%$ of the territory; planted pastures $13 \%$; and native ones $8 \%$ (MIRANDA, 2017). On the other hand, from January 2019, with the new Brazilian government of Jair Bolsonaro, satellite data from Brazil's National Institute for Space Research (INPE) show a significant increase in Amazon deforestation and an expansion of the exploratory agricultural frontier (KAMIMURA; SAUER, 2019). This increase in deforestation is related to the President's aggressive discourse and policies for economic development by promoting agriculture and mining on protected lands (ESCOBAR, 2019). Not surprisingly, the current government denies that humans have a direct impact on climate change and elects a foreign minister who believes global warming is an "invention of Marxist ideology" (FERRANTE; FEARNSIDE, 2019).

The president's policies loosen legislation and weaken institutions that help fight deforestation, as well as the participation of civil society and NGOs concerned with environmental preservation (RODRIGUES et al., 2019). A clear example is the flexibility of the forest code by President Bolsonaro and the Minister of Agriculture, Tereza Cristina Dias, which includes a longer deadline for ruralists to restore natural vegetation in illegally deforested areas (FERRANTE \& Fearnside, 2019).

Besides, the new minister Ricardo Salles, very close to the ruralists and condemned for altering an environmental plan to benefit the companies (PEREIRA; VIOLA, 2019), extinguished the Secretariat of Climate Change and Forests, early in the government. This fact has impacted Brazil's relationship with project donor countries, such as Norway and Germany, and has shaken international relations and the execution of important projects and partnerships, such as the Amazon Fund. These political decisions drastically affect Brazil's role in the fight against deforestation and environmental preservation, which are fundamental for reducing greenhouse gas emissions.

No other country in the world, not even the major agribusiness players, has the same conditions as Brazil to advance sustainable food production in the coming decades, and the governments must understand this position. The old idea of agricultural expansion through advancement in forested areas must be abandoned in favor of more integrated agriculture. Countries like China are already preparing to dominate the world agri-environment scenario in a clear vision of true patriotism, which implies protecting their people and dialoguing with the rest of the world for political empowerment (GUAN, 2019; LIU et al., 2015).

Meanwhile, Brazil, which has agri-environmental technology and a biodiverse landscape to assume this scenario, is still assuming a light idea of patriotism and betting on the old bankrupt commodity model. The danger of this nationalism so defended by the current Brazilian government, as well as other countries in the world, is worrying as it leads to separation, war, and conflict, while the practical solution to the challenges of climate change lies in cooperation between countries. No country can solve climate change issues on its own. Extreme nationalism, therefore, limits humanity's ability to deal with the current and future challenges the planet will face (HARARI, 2018). 
Brazil has a structure of science and innovation that has recently produced an unprecedented revolution in the rural zone, as well as farmers that are creative, enterprising and sensitive in incorporating new technologies into production. Pasture area which functions below its productive capacity still occurs, which represents room for growth in production and productivity, without opening new productive areas (EMBRAPA, 2018).

Thus, it is clear that Brazil's significant competitive advantage in the international scenario for the next decade is sustainable development, combining efficient agricultural production and preservation of natural environments. Since 2009, Brazil has taken on a massive role in this agenda, when it made voluntary commitments to reduce GHG emissions and adapt to climate change. Brazil's position in the negotiation motivated other developing countries to submit voluntary commitments.

The proposals presented in Copenhagen were internalized in the National Policy on Climate Change. In 2010, in order to achieve this commitment Sector Plans were created, including the Low Carbon Agriculture Plan (ABC Plan, from the acronym in Portuguese). In addition to Copenhagen, in 2015, Brazil submitted to the UNFCCC its intended Nationally Determined Contribution (iNDC), in the context of negotiations on a protocol, other legal instruments, or outcomes legally agreed upon under the Convention, applicable to all Parties.

This new commitment, made in addition to the one proposed by Brazil at COP15, reinforces the consolidation of low carbon agriculture and, in particular, the recovery of degraded pastures and ICLF as a real way to achieve the sustainable intensification of agricultural production. These technologies, beyond their ability to contribute to the mitigation of GHG emissions, may have the potential to increase productivity, income, and social benefits to farmers and consolidate sustainable rural development (RODRIGUES et al., 2019).

\section{CONCLUSIONS}

Following the ratification of the Kyoto Protocol, in 2009, Brazil made a voluntary commitment to reduce GHG emissions and, with the Paris Agreement in 2016, a new commitment to further reduce GHG emissions in some sectors. It is noteworthy that both the voluntary commitment made at COP15 and the commitment made at COP21 through the NDCs are not actions linked to the commitment of Annex I countries to the Kyoto Protocol. All actions reported in this paper have demonstrated not only Brazil's commitment to contribute to the negotiations under the Convention, but also its interest in making the country's economy a world reference, based on the sustainable use of its natural resources and optimization processes involving all sectors of the economy.

Since the founding of the UNFCCC during Rio 92, Brazil has shown immense leadership in international negotiations and gained respect from all parties. All this effort has shown Brazil's commitment and prominent role in promoting actions to reduce global warming and the development of a more sustainable economy.

However, this scenario is already change dramatically with the new policies and decision-making of the current government, which took office in 2019. Current political leaders deny the anthropic impacts on global climate change and weaken institutions that promote environmental preservation and oversee the deforestation.

While most emissions are the responsibility of developed countries, the countries that will be most affected by the catastrophic consequences of climate change are developing and underdeveloped countries. So as long as the current government does not leverage the actions proposed by the climate change mitigation agenda, the country's economic development is doomed to failure. 
Future challenges, given population growth, the effects of climate change, technological advances, and inequality in income distribution and concentration, significantly increase the importance of international negotiation and effective mechanisms for regulating the planet's climate. For this to happen, it is necessary to establish a new economic model, giving up the extreme nationalism advocated by the current Brazilian government.

Therefore, Brazil's consolidation as the world's first green energy (in agriculture and environmental preservation) must be worked on as a country, not as a government agenda.

\section{REFERENCES}

ARTS, B.; INGRAM, V.; BROCKHAUS, M. The Performance of REDD+: From Global Governance to Local Practices. Forests, v. 10, n. 10, p. 837, out. 2019.

BRAZIL. Brazil's Nationally Appropriate Mitigation ActionsBrazil, 2010. Disponível em: <https://unfccc.int/files/ focus/mitigation/application/pdf/brazil_namas_and_mrv.pdf>. Acesso em: 25 out. 2019

BRAZIL. Brazil Intended Nationaly Determined Contribution (INDCs), 2015. Disponível em: <https://www4. unfccc.int/sites/submissions/INDC/Published\%20Documents/Brazil/1/BRAZIL\%20iNDC\%20english\%20FINAL. pdf>. Acesso em: 25 out. 2019

CENCI, D. Climate Change: Paradoxes in the Implementation of Agreements and Protocols in Latin America and Brazil. In: Latin America in Times of Global Environmental Change. [s.l.] Springer, 2020. p. 157-170.

DIMITROV, R. S. Inside UN climate change negotiations: The Copenhagen conference. Review of policy research, v. 27, n. 6 , p. $795-821,2010$.

EMBRAPA. Visão 2030: o futuro da agricultura brasileira - Portal Embrapa. Disponível em: <https://www. embrapa.br/visao/o-futuro-da-agricultura-brasileira>. Acesso em: 25 nov. 2019.

ESCOBAR, H. Brazilian president attacks deforestation data. Science, v. 365, n. 6452, p. 419-419, 2 ago. 2019.

FERRANTE, L.; FEARNSIDE, P. M. Brazil's new president and 'ruralists' threaten Amazonia's environment, traditional peoples and the global climate. Environmental Conservation, v. 46, n. 4, p. 261-263, dez. 2019.

FRONDIZI, I. M. DE R. L. O Mecanismo de Desenvolvimento Limpo: guia de orientação-2009. Rio de Janeiro: Imperial Novo Milênio, 2009.

GUAN, J. Climate Change Policies in China. In: HEFELE, P. et al. (Eds.). . Climate and Energy Protection in the EU and China: 5th Workshop on EU-Asia Relations in Global Politics. Cham: Springer International Publishing, 2019. p. 121-128.

HARARI, Y. N. 21 Lessons for the 21st Century. [s.l.] Random House, 2018.

IPCC, C. C. Climate change: the IPCC scientific assessment. New York: Cambridge University Press, 1990. Disponível em: <https://www.nrel.colostate.edu/assets/nrel_files/labs/ryan-lab/pubs/Melillo_et_al_1990_IPCC1_WG1. PDF>. Acesso em: 25 out. 2019.

KAMIMURA, A.; SAUER, I. L. Amazon Deforestation and the Tragedy of the Commons. Unpublished, 2019.

KUMARI, S. et al. Methane Emission Assessment from Indian Livestock and Its Role in Climate Change Using Climate Metrics. Climate Change and Agriculture, 5 jun. 2019. 
LESNIEWSKA, F.; SIEGELE, L. The Talanoa Dialogue: A Crucible to Spur Ambitious Global Climate Action to Stay within the 1.5 Degree Celsius Limit. Carbon \& Climate Law Review (CCLR), v. 2018, p. 41, 2018.

LIU, Z. et al. Climate policy: Steps to China's carbon peak. Nature, v. 522, n. 7556, p. 279-281, jun. 2015.

MAAMOUN, N. The Kyoto protocol: Empirical evidence of a hidden success. Journal of Environmental Economics and Management, v. 95, p. 227-256, 2019.

MENDES, T. DE A. Desenvolvimento sustentável, política e gestão da mudança global do clima: sinergias e contradições brasileiras. Brasília: Universidade de Brasília, 2014.

MIGUEZ, J. D. Equity, responsibility and climate change. Ethics, Equity and International Negotiations on Climate Change, Edward Elgar, Northampton, p. 7-35, 2002.

MILKOREIT, M. The Paris Agreement on Climate Change-Made in USA? Perspectives on Politics, p. 1-19, 2019.

MIRANDA, E. E. DE. Meio ambiente: a salvação pela lavoura. Ciência e Cultura, v. 69, n. 4, p. 38-44, 2017.

MOSS, R. et al. Towards new scenarios for the analysis of emissions: Climate change, impacts and response strategies. [s.I.] Intergovernmental Panel on Climate Change Secretariat (IPCC), 2008.

OBSERVATÓRIO DO CLIMA. COP24 entrega regras claras, mas países precisam querer jogar - Observatório do Clima. Disponível em: <http://www.observatoriodoclima.eco.br/cop24-entrega-regras-claras-mas-paisesprecisam-querer-jogar/>. Acesso em: 25 nov. 2019.

OPOKU, A. Biodiversity and the built environment: Implications for the Sustainable Development Goals (SDGs). Resources, Conservation and Recycling, v. 141, p. 1-7, 1 fev. 2019.

OPPENHEIMER, M. et al. The Limits of Consensus. Science, v. 317, n. 5844, p. 1505-1506, 14 set. 2007.

PEREIRA, J. C.; VIOLA, E. Catastrophic Climate Risk and Brazilian Amazonian Politics and Policies: A New Research Agenda. Global Environmental Politics, v. 19, n. 2, p. 93-103, 24 abr. 2019.

RODRIGUES, D. F.; GALVÃO, V. K. Atores e instituições na formulação da Política de Mudanças Climáticas no Brasil. Sustentabilidade em Debate, v. 9, n. 1, p. 145-157, 2018.

RODRIGUES, R. DE A. R. et al. The actions of the Brazilian agricultural sector in the context of climate change negotiations. Sustentabilidade em Debate, v. 10, n. 2, p. 28-37, 31 ago. 2019.

SANDBERG, M.; KLOCKARS, K.; WILÉN, K. Green growth or degrowth? Assessing the normative justifications for environmental sustainability and economic growth through critical social theory. Journal of Cleaner Production, v. 206, p. 133-141, 1 jan. 2019.

SFORNA, G. Climate change and developing countries: from background actors to protagonists of climate negotiations. International Environmental Agreements: Politics, Law and Economics, v. 19, n. 3, p. 273-295, 2019.

SHARMA, P.; PAYAL, P. Climate Change and Sustainable Development: Special Context to Paris Agreement. Available at SSRN 3356829, 2019.

UNFCCC. United Nations Framework Convention on Climate Change, 1992. Disponível em: <https://unfccc.int/ sites/default/files/conveng.pdf>. Acesso em: 25 out. 2019 
UNFCCC. United Nations Framework Convention on Climate Change. Implementation of the Berlin Mandate, 1997. Disponível em: <http://unfccc.int/cop3/resource/docs/1997/agbm/misc01a3.htm>. Acesso em: 25 out. 2019

UNFCCC. Kyoto Protocol to the United Nations Framework Convention on Climate Change, 1998. Disponível em: <https://unfccc.int/resource/docs/convkp/kpeng.pdf>. Acesso em: 25 out. 2019

UNFCCC. Report of the Conference of the Parties on its thirteenth session, held in Bali, 2008. Disponível em: <https://unfccc.int/resource/docs/2007/cop13/eng/06a01.pdf>. Acesso em: 25 out. 2019

UNFCCC. United Nations Framework Convention on Climate Change. Paris Agreement, 2015. Disponível em: $<$ https://unfccc.int/sites/default/files/english_paris_agreement.pdf>. Acesso em: 25 out. 2019

UNFCCC. United Nations Framework Convention on Climate Change. Talanoa Dialogue Platform, 2018. Disponível em: <https://unfccc.int/process-and-meetings/the-paris-agreement/the-paris-agreement/2018talanoa-dialogue-platform>. Acesso em: 25 out. 2019

UNFCCC. Report of the Conference of the Parties on its twenty-fourth session, held in Katowice from 2 to 15 December 2018, 2019. Disponível em: <https://unfccc.int/sites/default/files/resource/10a1.pdf>. Acesso em: 25 out. 2019

UNITED NATIONS CLIMATE CHANGE. The Katowice climate package: Making The Paris Agreement Work For All | UNFCCC. Disponível em: <https://unfccc.int/process-and-meetings/the-paris-agreement/katowice-climatepackage>. Acesso em: 25 nov. 2019.

USDA. USDA Agricultural Projections to 2026. Disponível em: <http://www.ers.usda.gov/publications/pubdetails/?pubid=82538>. Acesso em: 25 nov. 2019. 